\title{
DARI RITUAL MENUJU KOMERSIAL: PERGESERAN TRADISI RUWAHAN DI KELURAHAN SUKOREJO, KECAMATAN WONOSARI, KABUPATEN KLATEN
}

\author{
Kinanti Bekti Pratiwi \\ Universitas Sebelas Maret \\ e-mail: artkinan8@gmail.com
}

\begin{abstract}
Ruwahan tradition actually come from Hindhu tradition. This ritual is changed after the Islam religion embarced by Javanese society. The aims of this paper is to explore the transformation or revolution this ruwahan ritual or tradition in Sukorejo, Wonoasri, Klaten residency. The object of this reseacrh is the society or social grups that are done this ritual. The paradigma in this paper is sociological kwowledge in social theory. The result of this research is that, the first, the transformation of this ritual happened when Islam value combinated with logic and modern thought. The second, the transformation this tradition appeared became comercial and economic factor. And then, many social grups participated in this tradition, such as acording gender and sex class, social ecomonic structure, etc. The economic factor in this tradition is caused by development Klaten as small urban city.
\end{abstract}

Key words: ruwahan tradition, economic, cultural transformation

\begin{abstract}
ABSTRAK
Tradisi ruwahan sebenarnya adalah peninggalan ajaran agama Hindu. Selanjutnya, ritual ini diubah sering masuk agama Islam dalam masyarakat Jawa. Tujuan penelitian ini adalah mengungkapkan pergeseran atau perubahan ritual ruwahan di Sukorejo, Wonosari, Klaten. Objek kajiannya adalah masyarakat desa itu yang melakukan ritual ini. Sudut pandang yang digunakan adalah sosiologis. Hasil yang dicapai dalam tulisan ini ada beberapa. Pertama, persegeran itu karena masuknya nilai-nilai Islam yang dipadukan dengan aspek akal dan pikiran. Kedua, perubahan muncul dari tradisi untuk kegiatan ritual spritual menjadi aspek komersial dan ekonomi. Ketiga, keterlibatan warga menjadi plural dan semua aktif dalam hal komersialisasi atau persoalan ekonomi dan hiburan kecil dalam konteks perubahan urban culture dalam pembangunan kota Klaten.
\end{abstract}

Kata kunci: tradisi ruwahan, ekonomi, pergeseran budaya 


\section{PENDAHULUAN}

Budaya adalah bentuk jamak dari buddhi (budi) dan daya (akal) yang berarti akal pikiran manusia. Budaya adalah cara hidup masyarakat yang berkembang dan diwariskan dari generasi ke generasi. Kebudayaan adalah keseluruhan gagasan dan karya manusia, yang harus dibiasakannya dengan belajar, beserta keseluruhan dari hasil budi dan karya itu. Budaya meliputi segala hal yang dilakukan oleh manusia dengan menggunakan akal pikiran manusia. Budaya umumnya berkembang dan dimiliki oleh sebuah kelompok masyarakat umum yang menerima suatu kebiasaan yang diturunkan oleh para pendahulu mereka dan sepakat melestarikan budaya tersebut. Suatu masyarakat yang memiliki kesadaran untuk menjaga hal baik yang telah diturunkan oleh leluhur dan biasanya kebudayaan ini berkembang di masyarakat yang masih mengenal mistis dan ontologis.

Penelitian mengenai tradisi dan upacara dalam masyarakat Jawa telah dilakukan oleh berbagai peneliti. Salah satunya adalah Wardani dan Soebijantoro (2017: 66-80). Hasil penelitian itu menunjukkan bahwa upacara tradisi dalam masyarkat Jawa berhubungan dengan makna historis dan perwujudan syukur pada Tuhan. Hal itu juga senada dengan yang diungkapkan oleh Mulder (1984) yang mengemukan bahwa upacara tradisi berhubungan dengan nilai-nilai atau pandangan hidup yang disimbolisasikan. Smentara itu, simbolisasi itu sendiri juga berhubungan dengan kepercayaan adan agama, seperti nilai-nilai spritualitas Islam. Jadi, kebudayaan Jawa juga tidak terlepas dari landasan agama Islam (Partokusumo, Karkono, Kamajaya, 1995). Namun, persegeran makna dan bentuk juga terjadi seiring dengan perubahan zaman ataupun pergeseran dengan nilai-nilai agama, terutama Islam. Hal itu sebagaimana dicontohkan dalam penelitian Setiawan (2016) tentang tradisi mitoni. Topik serupa juga diteliti oleh Mustaqim (2017:120-140). Sementara itu, Machmudah (2016: 1985-196) mengemukan tentang tradisi dan ketahanan ekonomi. 
Persoalan-persoalan tradisi atau ritual kebudayaan sering kali dibenturkan dengan nilai agama ataupun persoalan ketahanan atau kerukunan masyarakat. Tradisi ruwahan dalam masyarakat Jawa juga tidak terlepas pada posisi iti, seperti di daerah Sukorejo, Klaten ini. Persoalan serupa juga pernah dieksplorasi oleh para peneliti yang lain meskipun dengan objek material dan wilayah yang berbeda. Mereka diantaranya adalah Sarwana (2007), Astuti (2010), dan Irmawati (2013). Mereka mengungkapkan tentang gagasan terjadinya perbedaan makna, pergeseran, dan tantangan dari perubahan zaman atau waktu akibat pola dan pikiran orang yang terus berubah. Namun, hal itu sebenarnya bukanlah sebuah masalah yang serius, melainkan bagaimanakah pergeseran tersebut dimaknai dan dilakukan sebagai kebutuhan dan cara hidup manusia yang melakukan tuntutan untuk kehidupan yang lebih baik.

Selain bertujuan untuk mengungkapan nilai-nilai kearifan lokal, tradisi ruwahan di Kecamatan Wedi, tepatnya di Desa Sukorejo mengalami pergeseran karena persoalan modernitas dan arus informasi. Selain itu, nilai praktis dari tradisi itu sudah mengeser dan memandang tradisi ruwahan tidaklah terlalu penting bagi generasi berikutnya. Sebagai orang memiliki anggapan bahwa tradisi ini dipandang sebagai tradisi yang kuno dan sudah tidak sesuai dengan arus zaman masa kini. Namun, tradisi ruwahan ini pada dasarnya memiliki nilai-nilai simbolis sebagai bagian ajaran atau pelajaran yang baik bagi masyarakat. Hal ini sesuai dengan pandangan bahwa tradisi dapat menyesuaikan diri dan sekaligus memiliki nilia-nilai yang simbolis hingga perpaduan dengan nilai-nilai ajaran agama seperti Islam (Sholikin, 2010).

Tradisi ini masih banyak ditemukan di tengah masyarakat, khususnya masyarakat Jawa yang masih percaya dengan adanya mitos dan tahayul. Tradisi ini memang sudah banyak mengalami perubahan sesuai dengan perkembangan masyarakat. Masyarakat tidak banyak yang melakukan tradisi ini karena tradisi ini dianggap kuno dan tidak kekinian. Tulisan ini memaparkan beberapa kebaikan tradisi ini dan mengenalkan kembali pada kaum muda tentang tradisi ruwahan. Selain itu, persoalan pergeseran tradisi 
ruwahan ini juga menjadi fokus kajian utamanya. Pergeseran itu dimulai dari tujuan prosesi ruwahan dari mulai keliling desa, bersih desa, sampai kegiatan padusan yang sering dilakukan sebelum datangnya bulan puasa.

Kearifan lokal adalah sutu kekayaan budaya lokal yang dimiliki daerah tertentu yang mengandung pandangan hidup. Hal ini serupa dengan kebudayaan sebagai bagian dari kearifan hidup (Sutiyono, 2013). Walaupun ada usaha untuk mewariskan kearifan lokal dari generasi kegenerasi, hal ini tidak menjamin bahwa kearifan lokal itu tetap kukuh dan terjaga dalam menghadapi situasi globalisasi yang sekarang ini. Sebab, globalisasi menawarkan sebuah gaya hidup yang semakin praktis dan komunikatif. Secara fakta, hal ini dapat dilihat dari cara kearifan lokal yang menyimbolkan kebijakan dan filosofi hidup nyaris tidak terimplementasikan dalam praktik hidup. Pergeseran akibat globalisasi ini memungkinkan kearifan lokal bertransformasi secara lintas budaya yang pada akhirnya melahirkan sebuah nilai budaya.

\section{TEORI DAN METODE PENELITIAN}

Untuk menjelaskan praktik sosial suatu masyarakat, hal yang perlu dilakukan adalah memahami fakta tersebut, yakni apakah hal itu sebuah realitas atau sebuah hasil konstruksi. Suatu realitas sosial pada dasarnya merupakan sebuah konstruksi individu atau sosial yang perlu dimaknai. Gagasan tentang proses-proses tersebut pada dasarnya telah dijelaskan oleh Berger dan Luckman. Menurutnya, proses sosial itu perlu dimaknai sebagai sebuah kontruksi sosial (Maliki, 2012: 294-296).

Praktik sosial merupakan produk dari manusia. Masyarakat adalah sebuah realitas yang objektif. Untuk memahami praktik sosial itu, hal yang utama adalah mengetahui tujuan atau konstruksi atas praktik sosial tersebut. Selanjutnya, realitas dalam masyarakat itu dipahami berdasarkan hasil konstruksi tersebut. Selanjutnya, hal itulah yang dipandang sebagai produk dari masyarakat. Jadi, ada arena yang dilakukan, yakni pertama individu dan 
kedua adalah masyarakat. Sementara fakta sosialnya atau realitasnya adalah produk dari keduanya (Berger dan Lukmann, 1966:19-23). Pemahaman terhadap pergeseran tradisi ruwahan di Kecamatan Wonosari ini didasarkan atas pandangan itu. Tradisi ruwahan merupakan sebuah konstruksi individu. Sementara, fakta atau realitas yang terjadi di masyarakat perlu dipahami sebagai bagian dari produk bersama dari hasil konstruksi bersama.

Berdasarkan gagasan teoritis tersebut, metode penelitian ini adalah metode kualitatif. Metode kualitatif dipilih untuk mendapatkan data berupa informasi yang tidak dapat di hitung dengan angka dan menyesuaikan keadaan di lapangan tempat data digali dan mengacu pada subjek yaitu orang-orang dan masyarakat yang dijadikan sebagai sumber informasi (Sutopo,2006). Peneliti secara langsung terlibat dalam prosesi tradisi ruwahan dan melakukan pengamatan atas kejadian itu dari sebelum masa terjadinya dan sesudahnya, di Dusun Jurug, Kelurahan Sukorejo, Kecamatan Wonosari, Kabupaten Klaten.

Objek utama dari penelitian ini adalah tradisi ruwahan dari masyarakat tersebut. Selain observasi, teknik pengumpulan data dengan metode wawancara juga dilakukan dengan beberapa tokoh masyarakat dan warga di desa tersebut yang terlibat dalam tradisi ruwahan. Mereka adalah Bapak Igud Haryono (warga Kelurahan Sumber, Kecamatan Banjarsari, Surakarta, pada tanggal 02 Juni 2015, Bp. Harso Suwiryo, warga Desa Jurug, Kecamatan Wonosari, Klaten, pada tanggal 03 Juni 2015, Bapak Bambang Suparman, warga Desa Jurug, Kecamatan Wonosari, Klaten pada tanggal 03 Juni 062015.

Teknik interpretasi data dilakukan dengan mendasarkan pada beberapa langkah, yakni tahap deskripsi ruwahan sebagai bagian dari konstruksi sebagai satu individu. Selanjutnya, langkah yang dilakukan adalah dengan memberikan interpretasi sebagai bagian dari struktur atau produk sosial masyarakat tersebut. Pergeseran dari makna dan nilai tradisi dalam masyarakat itu dapat ditentukan dengan interpretasi antara individu dan realitas masyarakatnya. 


\section{HASIL DAN PEMBAHASAN}

\section{Tradisi Ruwahan sebagai Praktik Individual}

Berdasarkan pada wawancara yang telah dilakukan, tradisi ruwahan pada dasarnya dilakukan oleh para individu sebagai bentuk syukur dan permohonan ampun pada leluhur mereka. Hal ini mereka lakukan dengan cara mengirim doa pada para leluhur mereka yang telah meninggal dunia. Ruwahan yang berasal dari kata dasar ruwah yang berarti "arwah". Jadi, tradisi ini adalah acara ritual sebagai sarana pengirim doa untuk arwah leluhur dan para pendahulu sebagai sarana permintaan pengampunan dosa untuk para leluhur.

Menurut mereka, yang diwariskan secara turun menurun, ruwahan merupakan bulan ke delapan dalam penanggalan Jawa, tepatnya 10 hari sebelum bulan puasa yang sistem penanggalannya menggunakan sistem peredaran bulan seperti sistem penanggalan dalam Islam yang juga menggunakan penanggalan bulan. Namun, kedua hal ini sedikit berbeda sebab dalam penanggalan Jawa berakhir atau berganti tanggalnya selepas pukul 13.00--14.00. Namun, penanggalan Islam berakhir atau selesai pada selepas terbenamnya matahari atau saat masuk shalat maghrib.

Bagi mereka, tradisi ini merupakan suatu kewajiban sosial dan ada juga yang menganggap sebagai kewajiban religi terhadap keluarga atau para leluhur mereka. Mereka melakukannya kadang kala hanya secara sadar sebagai bagian dari mitos dan kebiasaan yang diajarkan oleh para orang tua mereka. Sebagai wujudnya, mereka melakukan tradisi ini. Tradisi ruwahan ini adalah kegiatan yang dilakukan oleh sebuah kelompok masyarakat di suatu daerah dengan melakukan beberapa ritual sebagai rangkaian acaranya sebagai praktik individual atas dasar kewajiban spritual dan kewajiban tradisi. Kegiatan ritual dalam acara ruwahan biasanya dipimpin langsung oleh kepala desa atau tetua desa tempat diadakan ruwahan tersebut (wawancara dengan Harso, 70 tahun).

Sebagai praktik individual, mereka hanya sekarang mengikuti berbagai tahap dari tradisi ruwahan ini. Tahap-tahap itu diantaranya terdiri dari berbagai ritual. Dalam tradisi ini, beberapa tahap kegiatan dilakukan. Pertama adalah 
ritual keliling desa atau lek-lekan (bangun malam). Ritual ini adalah ritual keliling desa yang biasanya dilakukan bersama oleh penduduk untuk memberitahukan bahwa bulan puasa akan segera datang. Lalu, pada malam harinya, mereka diadakan lek-lekan atau bangun malam. Bangun malam biasanya dilakukan oleh kaum pria dengan tujuan untuk memastikan suasana nyaman pada saat akan menjelang puasa. Selain itu, tujuannya adalah untuk menjalin rasa persaudaraan antar warga. Kegiatan pada saat bangun malam ini adalah minum teh dan makan bersama sambil bercerita hingga ronda malam sampai dengan menjelang sholat subuh.

Kedua adalah bersih desa dan makam. Sebelum melakukan ritual bersih desa dan makam, seluruh warga ikut dikumpulkan di balai desa sambil menunggu kedatangan warga yang lain. Setelah datang waktu yang disepakati, mereka secara bersama-sama memulai acara bersih desa dan makam tersebut. Kegiatan ini dimulai dari membersihkan desa dari pusat desa sampai ke pinggir atau perbatasan desa. Setelah selesai, mereka menuju kuburan desa untuk membersihkannya makam secara bersama-sama. Setelah selesai, mereka kembali lagi ke pusat desa dan di pusat desa para ibu-ibu sudah bersiap menghidangkan makanan untuk dimakan bersama. Seusai makan bersama, para penduduk kembali ke rumah masing-masing.

Ketiga adalah ritual kenduri. Ritual ini dilakukan selepas para penduduk pulang dari membersihkan desa dan makam. Ritual kenduri adalah ritual membagi hantaran yang dibagikan kepada kerabat dan tetangga di sekitar rumah. Hantaran biasanya berisikan makanan tradisional, yang isinya tiga menu yang utama dan harus ada pada setiap hantaran, yaitu kolak, ketan, dan apem. Mereka secara sadar memahami bahwa hal itu memiliki nilai filosofi. Misalnya adalah kolak. Kolak yang manis bersantan memiliki simbol ajakan bersaudara agar membawa barokah yang manis dalam setiap hal. Begitu juga dengan ketan yang mewakili simbol merekatkan tali persaudaraan agar semakin erat dan dapat saling melengkapi dalam bermasyarakat. Apem secara sederhana sebagai simbol permintaan maaf atau saling memaafkan. 
Ritual yang terakhir adalah padusan. Padusan adalah acara mandi besar atau mandi untuk mensucikan diri dari segala dosa yang pernah dilakukan. Hal ini bertujuan agar terhindar dari hadast besar dan hadast kecil. Ritual ini dapat dilakukan di mana saja dengan syarat tempat yang digunakan harus bersih dan terhindar dari najis. Ritual ini dapat dilakukan di rumah ataupun di tempat wisata. Biasanya, para pemuda dan pemudi yang melakukan ritual ini di luar rumah. Hal yang terpenting dari ritual ini adalah kesucian diri setelah melakukan padusan tersebut (wawancara dengan Igud, 53 tahun).

Pemaknaan ritual ruwahan ini secara individual terlihat dari cara masyaraat atau warga dalam memahami ritual ini. Ritual ini dipahami sebagai bagian dari kewajiban untuk para leluhur mereka atau sebagai sarana ekspresi moralitas individu (Sumarsono, 2007). Selain itu, hal ini juga merupakan sebuah tuntutan atas kebiasaan dan kebudayaan setempat. Sebagai individu, mereka secara sadar melakukan ritual ini. Namun, kadang kalanya, mereka tidak memahami makna dan asal usul dari ritual ini. Secara umum, kadang kalanya, mereka hanya sekedar mengikuti kebiasaan dan para tokoh tertentu yang terus menerus melestarikan tradisi ini. Para tokoh inilah yang sesungguhnya menjadi kunci dari tradisi ruwahan sebagai praktik individual. Mereka memiliki sebuah kesadaran dan "kekuatan sosial" untuk sekedar memaksakan ataupun membiasakan tradisi ini pada warga yang lain.

Proses pembiasaan ini melalui pengetahuan dan "kekuatan sosial" yang mereka raih, simbol-simbol beserta modal yang terarah untuk membuat sebuah konstruksi individual menjadi sebuah konstruksi sosial atas tradisi ini. Fakta inilah yang memberikan bukti bahwa individu juga mampu membuat sebuah kebiasaan. Sementara itu, struktur akan menerimanya menjadi sebuah tradisi atau kebiasaan sekaligus. Gagasan ini serupa dengan pandangan terjadinya sebuah strukturasi atas keadaan ataupun konstruksi ruwahan atas individu menjadi sebuah konstruksi sosial. 


\section{Perubahan Makna dari Tradisi Ruwahan}

Pergesaran sebuah kebudayaan atau tradisi menjadi hal yang wajar. Sebab, semua kebudayaan akan mengalami sebuah transformasi atau perubahan untuk menyesuaikan kondisi sosial dan kultural sebagai satu cara hidup (Koentjaraningrat, 1987). Ruwahan bagi masyarakat ini memiliki beberapa tujuan dan fungsi. Dahulu, sebelum masuknya agama Islam, tradisi ini memiliki tujuan sebagai sarana pemujaan atau untuk mengagungkan para leluhur ataupun nenek moyang. Hal ini bertujuan agar arwah para leluhur memberkati dan menjaga penduduk. Hal ini dikarenakan pemikiran mitis para penduduk yang masih percaya kepada tulah arwah para leluhur. Namun, setelah agama Islam mulai diperkenalkan pada para leluhur, sedikit demi sedikit, tujuan dari tradisi ini mulai berubah.

Sejarah perubahan itu terjadi melalui penetrasi nilai-nilai Islam. Tradisi dan kebudayaan juga dilandasi pada nilai keislaman agar tetap terjaga pada akidah islaminya (Sholikin, 2010). Pada masa kini, tradisi ini digunakan sebagai sarana mengirimkan doa untuk para leluhur. Selain itu, ritual ini secara sosial dikonstruksi menjadi sebuah ritual yang secara sosial membawa manfaat, yakni untuk mempererat persaudaraan antara warga satu dengan yang lain. Hal ini dijadikan sebagai pengingat untuk manusia bahwa pada akhirnya semua akan mati dan agar manusia lebih dekat dengan Tuhan dengan cara menjalankan garis yang telah ditentukan atau peraturan-peraturan Tuhan. Gagasan inilah yang menjadi pokok perubahan dari nilai-nilai ruwahan dari masa lalu atau sisi historisitasnya. Sisi historis yang menekankan pada aspek masa lalu dari perubahan nilainya.

Sebelum ajaran Islam memaknai atau "mengislamkan" tradisi ini, tradisi ini didasarkan atas pemikiran mistis. Pemikiran mitis sendiri adalah pemikiran yang meliputi alam kebudayaan primitif. Hal ini dapat dikatakan bahwa masyarakat masih berpikir tentang keadaan budaya seperti zaman dahulu atau masa lalu. Mereka masih memiliki sebuah kepercayaan melalui hubungan sebab dan akibat yang ditimbulkan atas ritual tersebut. Pemikiran ini berbeda 
dengan masyarakat modern. Masyarakat atau orang modern mulai sekarang sudah berpikir secara rasional. Ilmu pengetahuan yang berasal dari kemerdekaan akal dan pikiran telah menguasainya sehingga masuklah dia pada zaman modern (Russell, 2007: 646-650). Pemikiran mitis masih dipengaruhi oleh kepercayaan masyarakat dengan hal yang bersifat gaib dan rahasia. Keadaan mitis ini didasari oleh pandangan bahwa manusia merasa dirinya terkepung oleh sebuah kekuatan-kekuatan gaib di sekelilingnya. Kekuatan gaib itu dapat diidentifikasikan sebagai kekuatan yang berasal dari atau alam raya hingga kekuasaan kesuburan atas daerahnya. Pemikiran inilah yang menyebabkan perasaan takut pada penduduk. Mereka percaya kalau tidak melakukan ritual tersebut desa yang mereka tempati akan mendapatkan bencana ataupun tidak mendapatkan perlindungan dari para dewa.

Perubahan makna dari ruwahan ini dapat dilihat dari pergeseran makna sebelum masuknya nilai-nilai agama Islam. Sebelumnya, mereka memandang bahwa tradisi ini berhubungan dengan dunia mistis dan kekuatan supernatural yang berasal dari dewa dan alam. Mereka melakukan itu untuk memberikan penghormatan dan berkah dari para leluhur mereka serta alam sekitar mereka, yaknin kekuatan alam. Orientasi ini diwujudkan dalam sebuah orientasi atas kekuatan gaib dan kekuatan yang diluat jangkauan akal pikiran manusia.

Namun, ketika nilia-nilai agama Islam memasuki tradisi dan alam pikiran manusia, tradisi ini justru dilihat dari sisi akal pikiran dan spritualitas. Secara akal pikiran atau logika, tradisi ini hanya sebagai salah satu sarana untuk berdoa kepada Tuhan agar arwah para leluhur mereka diterima oleh Tuhan. Selain itu, tradisi ini juga dimaknai sebagai sarana untuk persaudaran antar warga sekitar. Secara akal pikiran, pemaknaan tradisi ini tidak bertentangan dengan nilai-nilai agama Islam, yakni hanya sebagai satu sarana berdoa pada Tuhan. Namun, persoalan-persoalan ini juga membawa dampak yang lain. Gagasan mengenai puritanisme ajaran Islam ikut berperan dalam memahami tradisi ini sebagai bagian yang bukan dalam ajaran Islam sebab ajaran atau ritual ini tetap dipandang sebagai bagian dari ajaran agama Hindu tentang 
pemujaan. Namun, fakta tersebut di dalam masyarakat Sukorejo masih belum begitu terasa bila dibandingkan dengan daerah yang lainnya.

\section{Perkembangan Tradisi Ruwahan di Sukorejo}

Masyarakat ataupun tokoh masyarakat yang memiliki pengetahuan dan memiliki penguasaan historis memiliki gagasan yang berbeda. Mereka memandang bahwa tradisi ini sebenarnya ritual yang berasal dari agama Hindu. Baginya, tradisi ini pada dasarnya ditujukan untuk puja pada para dewa. Masyarakat yang menganut tradisi kebudayaan dan nilai agma Hindhu percaya bahwa mereka diselimuti ilmu gaib dan diberi perlindungan oleh dewa.

Sebagai konsekuensinya, mereka melakukan pemujaan untuk mengagungkan sang dewa sebagai tanda terima kasih atas perlindungan dan segala kesuburan. Namun, kepercayaan itu mulai memudar setelah masuknya agama Islam yang dibawa oleh para penyebaran agama Islam seperti para wali dan ulama pada masa lalu (Sholikin, 2007). Kepercayaan mereka terhadap kekuasaan Tuhan mulai terbangun sebagai satu kekuatan yang Maha Esa. Sejak itulah, segala ritual yang dilakukan pada saat ruwahan secara bertahap mulai beralih fungsi setelah masuknya agama Islam.

Kegiatan atau parktik sosial ruwahan termasuk dalam kebudayaan yang bersifat tradisi. Tradisi adalah hal yang termasuk kedalam pewarisan atau penerusan norma-norma, adat istiadat, kaidah-kaidah, dan aturan tertentu. Kegiatan ruwahan ini dapat diartikan sebagai suatu ritual yang diwariskan secara turun temurun oleh para pendahulu mereka atau nenek moyang kepada anak dan cucu. Tujuan dari ritual ini diturunkan agar tetap terjaga dan mengingat para leluhurnya. Sebab, para leluhur menyakini bahwa nilia-nilai kehidupan yang disimbolkan dalam tradisi ini dapat dijadikan sebagai pelajaran dan ajaran serta peringatan bagi generasi berikutnya. Mereka bertujuaan agar para generasi berikutnya dapat bertahan hidup dengan memaknai dari mengali arti dari tradisi tersebut. Namun, sebaliknya, 
kenyataan berbeda sebab justru tradisi ini dimaknai secara tekstual saja sebagai praktik yang harus ada sedemikian rupa secara fisik. Makna secara batiniah tidak pernah digali dan dipraktikkan secara nyata. Sebaliknya, serimonial sebagai tujuan yang utama.

Tradisi ruwahan mengalami revolusi yang cukup cepat. Revolusi adalah perubahan suatu keadaan secara bertahap dengan waktu yang cukup singkat. Hal ini dimulai dari tujuan sampai kegiatan ritual ruwahan. Semua hal itu sudah sangat berubah dari masa-masa sebelumnya. Sebagai contohnya, masyarakat sudah jarang melakukan upacara untuk tradisi ruwahan. Ataupun, tradisi ini telah mengalami berbagai perubahan dan modifikasi dari sebelumnya. Perubahan itu bukan hanya dari sisi fisik ritual, perlengkapan, formula ritual, ataupun prosesinya, tetapi perubahan itu terjadi juga pada tujuan dari ritual ini.

Sebagai contohnya adalah perubahan dari makna ritual ini. Sebagai besar masyarakat di desa ini memandang ritual itu sebagai sesuatu yang lampau dan kuno. Sekarang ini, ritual ini jarang ditemukan apa lagi di daerah perkotaan. Sebagai kecil masyarakat saja melakukan tradisi ini. Khususnya, masyarakat di daerah pedesaan masih melestarikan atau mempraktikan ritual ini meskipun telah terjadi berbagai penyesuian dan perubahan.

Contohnya dari hal itu adalah daerah Jurug, Sukorejo, ini. Masyarakat di desa ini masih melakukan tradisi ini setiap tahunnya. Perubahan itu terjadi sering dengan kemajuan teknologi dan era informasi. Tradisi ruwahan di desa ini sudah bnyaak mengalami perubahan, terutama pada ritual dan kegiatan yang dilakukan. Pertama, sebagian besar saja warga melakukan ritual ini dan sebagaian kecil lainnya mulai meninggalkan. Kedua, beberapa ritual yang dipandang tidak terlalu penting secara akal dan cara mengerjakan mulai ditinggalkan dan dignati dengan kegiatan yang lainnya. Sebagai contoh adalah ritual bangun malam yang diisi dengan kegiatan mengobrol dan makan bersama sekarang diganti dengan acara pasar malam. Hal ini memiliki makna secara ekonomis dan sekaligus memberikan hiburan kepada masyarakat. 
Aspek komersialisasi sudah mulai diperhitungkan sebagai cara untuk mengangkat persoalan ekonomi dan hiburan. Hal ini sesuai dengan pertumbuhan kebudayaan urban yang terpinggirkan dalam pembangunan kota.

Sebagai bagian dari kebudayaan urban yang terpinggirkan dan usaha untuk arah komersialisasi, pasar malam lebih menargetkan keterlibatan seluruh warga dari berbagai tingkat usia, gender atau jenis kelamin, hingga tingkat ekonomi. Pasar malam yang diadakan tentu saja menyediakan penjual dari desa itu ataupun luar desa. Hal ini menandakan ada keterlibatan ekonomi secara kecil dalam tradisi ruwahan. Penduduk yang terlibat bukan hanya dari desa itu, tetapi hal ini juga dapat berasal dari luar desa meskipun dalam jumlah yang tidak terlalu besar. Tujuan utamanya adalah hiburan dan perputaran ekonomi skala kecil sebagai bentuk latihan ketahanan ekonomi. Di pasar malam, para penjual hadir dalam berbagai bahan dagangan, yakni mulai pedagang makanan dan minuman, pedagang pakaian, pedagang peralatan rumah tangga serta banyak pula pedagang mainan anak-anak.

Selain itu, perubahan yang lain terlihat dari ritual kenduri yang tidak lagi dilakukan. Kegiatan kenduri yang tidak dilakukan digantikan dengan acara makan bersama oleh para penduduk yang tinggal di desa tersebut. Hal ini secara praktis dapat mengurangi kerepotan dan juga membawa aspek kebermanfaatan ekonomi bagi warga. Kenduri dianggap kurang praktis dan menghabiskan banyak waktu dan biaya. Waktu untuk bekerja tersita. Biaya yang dikeluarkan berjumlah banyak. Masyarakat desa ini mulai menggantinya dengan makan bersama seusai bersih desa dan bersih kuburan. Kegiatan yang dilakukan di desa itu sudah mengarah ke kegiatan yang modern dan memperhitungkan efektivitas dan efisiensi, baik dari segi biaya atau uang dan waktu yang produktif. Perkembangan ini tidak lepas dari kemajuan teknologi dan perkembangan informasi serta pertumbuhan pembangunan kota. Masyarakat mulai memiliki pemikiran yang serba cepat dan praktis karena teknologi yang sudah sangat canggih (wawancara dengan Bambang, 61 tahun). 
Ritual ruwahan sendiri pada akhirnya dinilai oleh para pelakunya dengan cara yang beragam. Pertama, beberapa warga masih setuju dengan ritual ini. Kedua, banyak warga atau sebagian besar warga mengganggap ritual ini kuno untuk dilakukan. Masyarakat yang mengatakan setuju dengan ritual ini beranggapan bahwa hal ini merupakan kewajiban untuk menjaga sesuatu telah diwariskan oleh leluhur. Mereka dapat melestarikannya dengan cara tetep melakukan ritual tersebut untuk menjaga tradisi kearifan lokal dan mengenalkan kepada anak dan cucu. Sebab, tradisi itu dipandang memiliki pelajaran yang baik dari setiap ritual dan sebagai sarana untuk mendekatkan pada sang pencipta. Sebaliknya, masyarakat yang tidak setuju memandang bahwa ritual tidak tepat berada di dunia modern seperti sekarang ini sebab cara mendekatkan diri pada Tuhan dapat dilakukan dengan cara yang lain dengan tidak memakan biaya dan waktu yang banyak. Selain itu, pelajaran nilai-nilai tradisi juga dapat diajarkan dalam bentuk yang lain. Toh, ritual itu sekarang hanya sekedar ritual atau seremonial tanpa ada pemahaman terhadap makna yang sesungguhnya. Ritual ini telah terkikis oleh kesibukan dan akitivitas hidup yang kian berat seperti aktivitas pekerjaan, ekonomi, dan urusan rumah tangga. (wawancara dengan Igud, 53 th).

\section{SIMPULAN}

Pergeseran tradisi ruwahan ini sangat terlihat dari fungsi secara sarana spritual dan penghormatan pada para leluhur menjadi aspek komersial atau kegiatan ekonomi desa. Tradisi ini dilakukan oleh sebagian umat Islam dan disesuaikan dengan nilai-nilai ajaran Islam. Ritual ruwahan berfungsi untuk mendoakan arwah para leluhur yang telah meninggal. Namun, sesaji sudah tidak lagi menjadi hal yang penting atau tidak lagi digunakan. Hal yang utama adalah kebersamaan dan mempererat persaudaraan sesama warga. Ritual ini tetap memiliki nilai kearifan lokal yang masih dipertahankan hingga sampai saat ini. Ritual ruwahan telah banyak melahirkan kebiasaan baru dalam masyarakat seperti aktivitas ekonomi, efesiensi biaya dan waktu. 
Perkembangan teknologi dan informasi telah mengkikis nilai-nilai dan pemikiran mistis para warga desa sehingga berdampak pada perkembangan ritual ini mengarah pada aspek logika dan akal sehat yang dilandasi nilai-nilai agama Islam.

\section{DAFTAR PUSTAKA}

Astuti, P.L. (2010). “Upacara Adat Perkawinan Priyayi Di Desa Ngembal Kecamatan Tutur Kabupaten Pasuran", Skripsi, Fakultas Ilmu Sosial, Universitas Negeri Malang, tidak diterbitkan.

Berger, P.L dan Luckmann, T. (1966). The Social Construction of Reality. New York: Double Day.

Koentjaraningrat. (1987). Sejarah Teori Antroplogi I. Jakarta: Universitas Indonesia Press.

Irmawati, W. (2013). Makna Simbolik Upacara Siraman Pengantin Adat Jawa. Jurnal Indigenous , Vol 21, No 2, 2013.

Machmudah, U. 2016. “Budaya Mitoni: Analisis Nilai Islam dalam Membangu Semangat Ekonomi", El-HARAKAH Vol 18, no. 2, Desember 2016, hlm. 185-198.

Maliki, Z. (2006). Rekonstruksi Teori Sosial Modern. Yogyakarta: Gadjah Mada University Press

Mulder, N. (1984). Kebatinan dalam Hidup Sehari-hari Orang Jawa: Jakarta: Gramedia.

Mustaqim, M. (2017). “Persegeran Tradisi Mitoni: Persinggungan Antara Budaya dan Agama", Jurnal Penelitian Vol. 11, No.1 Februari 2017, hlm. 120140.

Partokusumo, Karkono, Kamajaya. (1995). Kebudayaan Jawa, Perpaduanya dengan Islam. Yogyakarta: Aditya Media.

Russell, B. (2007). Sejarah Filsafat Barat; kaitannya dengan kondisi sosio politik zaman kuno hingga sekarang (penerjemah: Sigit Djatmiko dkk). Yogyakarta: Pustaka Pelajar.

Sarwana, S.F. (2007). Pelaksanaan upacara Perkawinan Adat Kraton dalam Pelestarian Nilai Budaya di Kabupaten Sumenep. Skripsi tidak diterbitkan, Universitas Negeri Malang.

Setiawan, E. (2016) “Nilai Religius Tradisi Mitoni dalam Perspektif Budaya Bangsa Secara Islami", Al-Adalah 18, No. 1, Maret 2016.

Sholikin, M. (2010). Ritual dan Tradisi Islam Jawa. Yogyakarta: Narasi.

Sumarsono. (2007). Tata Upacara Pengantin Adat Jawa. Jakarta: Buku Kita.

Sutiyono. 2013. Poros Kebudayaan Jawa. Yogyakarta: GRAHA ILMU.

Sutopo, H.B. 2006. Metodologi Penelitian Kualitatif: Dasar Teori dan Terapannya dalam Penelitian. Surakarta: Universitas Sebelas Maret.

Wardani, T.S. dan Soebijantoro. (2017). “Upacara Adat Mantu Kucing di Desa Purworejo Kabupaten Pacitan: Makna Simbolis dan Potensinya sebagai 
Kinanti Bekti Pratiwi - Dari Ritual Menuju Komersial: Pergeseran Tradisi 'Ruwahan' di Kelurahan Sukorejo, Kecamatan Wonosari, Kabupaten Klaten

Sumber Pembelajaran Sejarah" Jurnal Agastya, Vol. 7, No. 1 Jnauari 2017 hlm. 66-81. 